\title{
Impact of Brand Equity Drivers on Purchase Intention: A Moderating Effect of Entrepreneurial Marketing
}

\author{
Muhammad Raza * $\quad$ Reema Frooghi ${ }^{\dagger} \quad$ Dr. Shamsul Huda binti Rani ${ }^{\ddagger}$ \\ Muhammad Asif Qureshi §
}

\begin{abstract}
The study aimed to analyse the impact of brand image, brand perception, brand preference and brand loyalty on consumer purchase intention in the FMCG industry of Pakistan. It also used entrepreneurial marketing as moderator between the association of brand loyalty, brand perception, brand image and brand preference with purchase intention. The study has used quantitative explanatory research design. In this concern, a sample of 424 responses was collected using convenience sampling technique from different self-service stores and mega malls of Karachi city, Pakistan. Survey instrument was adapted from numerous past literatures and designed on fivepoint Likert measurement scale. The results and findings of the study showed that brand loyalty, brand perception and brand preference have statistically significant and positive impact on purchase intention. Among the three statistically significant variables, brand loyalty has most impact on purchase intention, followed by brand preference and least influenced by brand perception. Additionally, the results showed that entrepreneurial marketing moderates the relationship of brand loyalty, brand perception and brand preference with purchase intentions of consumer toward FMCG brands in Pakistan. However, the results interestingly showed that brand image does not influence purchase intention and also, entrepreneurial marketing does not moderate its relationship with purchase intention in regards to FMCG brands in Pakistan. The study also showed that combination of all the variables has strength to predict 34.1 percent of purchase intention in regards to FMCG brands of Pakistan. The study further provides conclusion, managerial recommendations and future research directions.
\end{abstract}

Keywords: Brand Image, brand loyalty, brand perception, brand preference, consumers' purchase intention, entrepreneurial marketing

\section{Introduction}

Marking research has been a concentration of advertising examination for more than 30 years. A brand is a name, term, sign, image, or plan, or a mix of these components, used to recognize the products as well as administrations of one association from contending firms (Kotler \& Armstrong, 2010). Keller and Lehmann (2003) expressed that "A standout

\footnotetext{
* Assistant Professor, Sindh Institute of Management and Technology, Business Administration, Pakistan.

${ }^{\dagger}$ Assistant Professor, Khadim Ali Shah Bukhari Institute of Technology, Department of Business Administration, Pakistan.

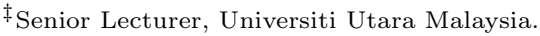

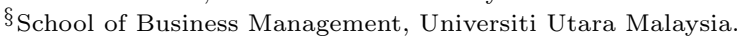


amongst the most profitable resources for any firm is the unclear resource spoken to by its brands," likewise, the advancement of brand value is maybe a standout amongst the most essential and helpful practices since advertisers can pick up an upper hand through effective brands (Lassar, Mittal, \& Sharma, 1995).

Brand equity is seen from an economic related or shopper point of view; however, past studies have shown that the buyer based perspective of brand value is most imperative since the estimation of a brand exists with customers (Keller \& Lehmann, 2003). D. Aaker (1991) and Keller (1993) made the establishment of client based brand value, which is multidimensional idea including brand mindfulness, perceived quality, mark associations, and brand certainty. Customer based brand value happens when buyers hold great, solid, and one of a kind brand relationship in memory (Keller, 1993).

Products/brands choice to purchase or reject relies on its image in the market. The improvement of this image has a ton of components behind it. These elements are composed and inserted in such a way, to the point that they are invited by every one of the buyers. For example, few purchasers estimated that organization has distinguishes their need and builds up a class of huge product range. Along these lines, this demonstrates, buyer impression of a brand is critical for example: Unilever has built up its own novel image personality and clients are currently very attentive of it. Accordingly, with regards to purchase an imaginative item with additional common components, the main name comes in clients essence is of Unilever. This is brand value and Unilever is offering its FMCG items on the foundation of their created image value. One most essential elements turned out from various inquires is the brand value. Analysts recommend that $65 \%$ of the FMCG items are bought in light of the brand value of the creator. In this manner, it is examined that the buyer buy aim and its association with the brand value must be evaluated.

In the past few decades, the concept of brand management has emerged prominently. The reason may lie in extensive and thriving competition in almost every industry, sector and economy, Koren, Wang, and Gu (2017). Regardless of economic crisis and financial distress, warfare and terrorism at peaks, the companies are striving hard now-a-days to gain competitive advantage and finding hard for winning strategies through engaging customers and consumer markets, Martins, Martins, and Pereira (2017); Walas and Celuch (2014). In the recent past, Marquardt, Kahle, O'Connell, and Godek (2017) has investigated brand equity using List of Values (LOV) measures, whereas, Dennis, Papagiannidis, Alamanos, and Bourlakis (2017); Menon and Barani (2016) analysed brand attachment as determinant to brand equity in higher education institutes. Similarly, Iglesias, Markovic, Singh, and Sierra (2017); Moussa and de Barnier (2017); Gürhan-Canli, Hayran, and Sarial-Abi (2016) also emphasized on estimating brand equity importance and implications to various domains. These evidences and empirical studies stressed on further exploration of brand equity drivers for novel and maneuvering dimensions of research, practice and comprehension.

Furthermore, the dimension of entrepreneurial marketing has recently come into limelight within the paradigms of practical implicative researches. The emergence of the entrepreneurial marketing can be traced way back in early to mid-90's, Ronstadt (1990); Chaston (1997); Gilmore and Carson (1999); Carson (1990, 1990). However, its implications and applicability to different research methodologies still have prominence to practice, 
evolve and explore. In this concern, the foremost important aspect is to assess its moderating effects on one of the popular brand management concepts of brand equity. Past literature lack extensively in providing adequate empirical evidence in marketing research. Though, its importance cannot be neglected anyway. Hence, the study aimed to analyse the impact of brand image, brand perception, brand preference and brand loyalty on consumer purchase intention in the FMCG industry of Pakistan. It also used entrepreneurial marketing as moderator between the association of brand loyalty, brand perception, brand image and brand preference with purchase intention.

In consumer psychology and behavior, the companies are paying special attention to diagnose, identify and understand their intentions and purchase behaviors deeply. The timely need of such specific and appealing directions from the corporates, literally enforces the academics and researchers to actively disseminate their understanding and knowledge extensively. The companies are well-concern about their marketing and branding strategies and focuses exclusively to customer relationship and engagement into their brands. Therefore, the needfulness of taking brand management seriously and understand its roots to marketing and consumer psychology has been identified by the current study. Thus, resting on the oldest school of thoughts regarding brand equity namely D. Aaker (1991) and Keller (1993), the study has focused on assessing brand image, brand loyalty, brand perception and brand preference as influencing factors for consumer purchase intention. The current study specifically and efficiently functions beneficially to FMCG sector companies of Pakistan, also, researchers and academics for deepen their understanding about brand equity management and its association with consumer behavior and psychology. But, it also facilitates the consumers to effectively utilize their perception and preferences and restrain their psychological and behavioral aspects to be overcame by fake and false offerings. The real value inherits in the product and service has to be communicated effectively and also, delivers customer services to its best. Therefore, the current study also encourages consumer awareness to better brand equity management.

\section{Theoretical Background}

Marketers globally reveal that customers' expectations and insights about brands are not limited to the beneficial and functional characteristics of the branded products and services. They often contain "brand image"; a non-functional quality; which comprises the set of human characteristics; "brand personality". Brands personality traits is the reason that customers' prefer to use the brands, while marketing researchers try to attract more customers' by highlighting their perceptions by better positioning their own brands with their competitors in a market (J. Aaker \& Fournier, 1995; Austin, Siguaw, \& Mattila, 2003).

J. L. Aaker (1997) with the title "Dimensions of Brand Personality", has developed a framework which constitute of five dimension defining personality of brand. Each divided into a set of facets. It is a model to describe the profile of a brand by using an analogy with a human being. The five core dimensions and their facets such as 1) Sincerity (down-to-earth, honest, wholesome, cheerful); 2) Excitement (daring, spirited, imaginative, up-to-date); 3) 
Competence (reliable, intelligent, successful); 4) Sophistication (upper class, charming) and 5) Ruggedness (outdoorsy, tough).

Morgan (2000) in his research has focused on antecedents of customer based perspective. The operationalization of customer-based brand equity can be divided into consumer perception (e.g. brand awareness, brand associations, perceived quality) and customer behaviour (e.g. brand loyalty, willingness to pay a high price). D. A. Aaker (1996) assumes that a loyal consumer base represents a barrier to entry, a basis for a price premium, time to respond to competitors, and against the deleterious price completion, and brand loyalty is a core dimension of brand equity. Additionally, brand image used by D. Aaker (1991) has defined brand image as a series of brand associations stored in a consumer's memory. Keller (1993) defined brand image as the sum the total of brand associations held in the memory of the consumers that lead to perceptions about the brand. Keller in his research has also also classified the associations of brand image into quality dimension and affective dimension. Another antecedent which is brand perceptions also has its significance in contributing customer purchase behaviour. Brand perceptions included functional, experiential and symbolic value generated (Berthon, Pitt, Parent, \& Berthon, 2009; Vigneron \& Johnson, 2004). Additionally, another antecedent which is brand preference has its significance in explaining customer purchase behaviour. Brand preference is defined as the degree to which a consumer is oriented towards buying well-known branded products (Shim \& Gehrt, 1996). Furthermore, this study used entrepreneurial Marketing as a moderation effect on purchase intention. Entrepreneurial marketing has been described as the marketing activities of small and new ventures (Janet \& Ngugi, 2014). It represents an exploration of ways in which entrepreneurial attitudes and behaviours can be applied to the development of marketing strategy and tactics (Janet \& Ngugi, 2014).

\section{Product and Brand}

The investigation of brands and items is not unique in the academic world. In the most recent century, Janet and Ngugi (2014); Gardner and Levy (1963) have stated that a large portion of essential issues identified with publicizing and deals were identified with the topic of customer mentality to the item and specifically the idea created in his brain with marks. Consequently, Gardner and Levy is the identity of the organization whereupon their dishonour is based.

In this sense, as per Janet and Ngugi (2014); Gardner and Levy (1963) the exploration indicated the time that the primary explanations behind individuals to utilize certain items were the favourable circumstances and detriments found in brands. In any case, this data was imperative for some recommendations; however, was not edifying on the grounds that it precluded an extensive number of circumstances.

Against this assertion, Janet and Ngugi (2014); Gardner and Levy (1963) find new thoughts to react to unavoidable issue identified with "A more prominent consciousness of social and mental nature of item" or brands, media, associations, institutional figures, administrations, businesses or thoughts. In this way, new rules and ideas are expected to correspond procedure between the supplies of products and people in general. Furthermore, few ideas were examined at that time significantly and they are motivation and product 
dimension, public image and a crucial symbol.

Janet and Ngugi (2014); Gardner and Levy (1963) in his reviews bear witness that wide assortment of ideas and techniques were connected to investigate the characteristics of the states of mind and inspirations of the general population. At new discoveries from specialists in connection to understand the states of mind and Personal sentiments have given the arrangement of concept brand and product image.

\section{Brand Equity and its Perspectives}

Brand equity can be defined as the value of having a well-known brand name, based on the idea that the owner of a well-known brand name can generate more revenue simply from brand recognition; that is from products with that brand name than from products with a less well-known name, as consumers believe that a product with a well-known name is better than products with less well-known names. It can be measured by the expansion in real money streams as consequence of the brand related with the item (Farquhar, 1989). Brand equity alludes to leftover resources coming of the impact of promoting exercises related with an image (Rangaswamy, Burke, \& Oliva, 1993). Brand equity includes esteem is inferable from the brand and is caught by relying upon brand execution of its characteristics (Sikri \& Ramaswami, 1992).

These creators assert that brand value is the consequence of its quality and brand esteem. The brand quality is originating from the arrangement of affiliations and customer conduct and the brand esteem reflects money related consequence of administration's capacity to use brand quality through strategic and key activities. Furthermore, the examination demonstrates the buyer point of view observing the brand value as "the buyer observes the brand value as the esteem added to item or administration by the brand".

D. A. Aaker (1996) characterized brand value as an arrangement of benefits connected to a brand's name and image that adds to the esteem given by an item". D. A. Aaker (1996) states to real resources for brand value as brand name mindfulness, mark certainty, perceived quality and brand affiliations. Such solid resource classes construct solid brands that make esteem.

This research explores around the impacts of brand value on buyer's aim to buy as it is required to examine the shopper base brand value. Client based brand value happens when the purchaser knows about the brand and holds some great, solid and one of a kind brand relationship in memory (Keller, 1993). Keller (1993) characterizes client based brand value as the differential impact of brand learning on customer reaction to the promotion of brand. Most reviews, previously, have concentrated on the effect of showcasing substance and offering methodologies of an advertisement message as an impact. In this manner, this is an opportune and viable key thought to concentrate the centre part of what makes individuals to purchase an item for example: visual, colour and illustrations, operating systems, size, usability and so forth if there should arise an occurrence of FMCG items. 


\section{Definitions of Consumer Brand Equity}

There have been various published articles endeavoring to conceptualize, characterize, and measure the brand value develop particularly from an individual customer point of view, or called customer brand equity. Winters (1991) said that if asking 10 individuals what brand equity is; one is probably going to find 10 or 11 unique solutions in the matter of what it implies. This section, thus, is proposed to completely survey those current calculated and operational meanings of the size from a correspondences stance. Complexly, it will assemble those reviews and investigate them as far as sections, and similarities and contrasts among definitions, and also solid and delicate purposes of existing definitions.

It is examined that reasonable definition implies reflection. It is the initial phase in the definition procedure to decipher any hypothetical thought from one's psyche into an important verbal message (Miller \& Nicholson, 1976). Calculated definition speaks to incorporate the substance of what a specific size implies. In any case, characterizing a size may be confused by difference among themselves about what must be shared view for the developed question (Jacoby, Chestnut, \& Fisher, 1978). Regarding the purchaser customer brand equity, there has for some time been equivocalness and perplexity on the exact conceptualization of the developed assertions. Various analysts have talked about their own reasonable definitions.

Given this issue, it would prompt the exchanges on particular purposes of assertion and difference among the current study. As Jacoby et al. (1978) call attention to, the last outcomes will be twofold. In the first place, shared implications might be accepted to speak to the vital centre of what customer brand equity is. Second, these calculated establishments will fill in as a reason for operational meanings of the idea later talked about.

Concentrates outlined essentially to conceptualize, classify, and characterize the equity as it has developed and created, from 1988 to date, and additionally calculated pieces that endeavour to position customer brand equity in connection to mental establishments, behavioural developments, or both. Articles in prominent magazines are avoided in light of the fact that they externally approached the idea. As specified, the survey introduced here spotlights on brand value as it identifies with an individual buyer, not as it has been exhibited comprehensively.

\section{Aaker's Theory of Brand Equity}

D. Aaker (1991) recommended that brand value has a few determinants that are practically interlinked with each other. These determinants incorporate brand mindfulness, brand association, brand loyalty and perceived quality. In addition, Keller (1993) hypothesis of brand value proposes that brand preference and brand judgment are two centre foundational blocks for creating brand value, while it prompts brand equity toward the end. Moreover, these parts and determinants of brand value including brand image, brand loyalty, brand preference and brand perception, significantly analyse and decide the aim of the buyers. In this way, through these two calculated and generally utilized models and speculations of brand value. The present review has intentionally built up the hypothetical establishments that brand image, brand loyalty, brand preference and brand perception 
have fundamentally assuming imperative part in the administration and comprehension of shoppers' purchase goal. Consequently, the present study has created taking after speculations on the premise of brand value hypotheses proposed by D. Aaker (1991) and Keller (1993).

$H_{1}$ : Brand perception significantly affects purchase intention.

$\mathrm{H}_{2}$ : Brand loyalty significantly affects purchase intention.

$\mathrm{H}_{3}$ : Brand image significantly affects purchase intention.

$\mathrm{H}_{4}$ : Brand preference significantly affects purchase intention.

\section{Entrepreneurial Marketing}

The term Entrepreneurial Marketing (EM) is used to describe the marketing activities of small and new ventures. Also, EM represents an exploration of ways in which entrepreneurial attitudes and behaviours can be applied to the development of marketing strategy and tactics (Janet \& Ngugi, 2014). In the current scenario the firms have been giving proper consideration related to the consideration of the potentialities of entrepreneurial marketing. It states available utilization and allocation of opportunities and resources which are available for the penetration in the market to gain revenue in bigger shares of market with techniques which are innovative (Martin \& Javalgi, 2016). It was highlighted in pervious literatures by the practitioners and researchers that the entrepreneurial marketing has ability to gain the significant importance for the future growth and it can gain the competitive edge and sustainable performance (Hernández-Perlines, 2016; Reijonen, Hirvonen, Nagy, Laukkanen, \& Gabrielsson, 2015; Thoumrungroje \& Racela, 2013). Basically, entrepreneurial marketing emphasizes on promoting brand or service using multiple marketing strategies to ensure widespread and extensive promotion of it. It also stresses upon engaging into different types of less labour-intensive but effective marketing strategies including relationship marketing, direct marketing and digital marketing, (Elvira \& Xhaferi-Elona, 2014; Hills, Hultman, \& Miles, 2008; Kilenthong, Hills, \& Hultman, 2015).

\section{Moderating Effect of Entrepreneurial Marketing}

In the recent decade, entrepreneurial marketing has gain enormous importance from researchers, practitioners and companies as well. Number of empirical literature and case studies has been published in the last few years including (Kowalik \& Duliniec, 2015; Yang \& Gabrielsson, 2017; Becherer \& Helms, 2016; Franco, de Fátima Santos, Ramalho, \& Nunes, 2014). Similarly, these empirical literatures provide adequate foundations to moderating effect of entrepreneurial marketing in business and brand management (Yang \& Gabrielsson, 2017; Becherer \& Helms, 2016). On the other side, it has been evidently proven that brand equity drivers cannot single-handedly gauge and manage consumers' purchase intention in today's scenario. Therefore, there is extreme need to involve some expert and dedicated efforts for consumerism, profit proliferation and strive for larger market share (Becherer \& Helms, 2016; Franco et al., 2014). Hence, the study has used entrepreneurial marketing as moderator to the association between brand equity drivers 
and purchase intentions of consumers. Thus, the study has hypothesized moderating effect of entrepreneurial marketing to proposed relationship as follows.

$H_{5}$ : Entrepreneurial marketing moderates the relationship between brand perception and purchase intention.

$H_{6}$ : Entrepreneurial marketing moderates the relationship between brand loyalty and purchase intention.

$H_{7}$ : Entrepreneurial marketing moderates the relationship between brand image and purchase intention.

$H_{8}$ : Entrepreneurial marketing moderates the relationship between brand preference and purchase intention.

\section{Review of the Literature}

Grohmann, Giese, and Parkman (2013) through an experimental review found that there has been a more prominent level of effect of brand value on buyer discrimination. Buyer favours those brands which have more grounded image in the market notwithstanding of the way that they are great in quality or not. As brand value has built up an observation in the brains of buyers in regards to its quality and esteem.

Cobb-Walgren, Ruble, and Donthu (1995) analyse brand equity issues and estimations, at that point connected the significance of promoting on buyer expectations. They found that brands included esteem, and this additional esteem was known as brand value. Brand equity created volume and productivity, giving stages to the presentation of new items. Cobb-Walgren et al. (1995) dissected chemicals and lodgings independently. Thus, they would have liked to touch base at substantial conclusions for merchandise and enterprises. The connection to publicizing was set up when it was discovered that organizations with higher promotion spending plans produced more brand value.

Blackston (1995) study the idea of added value as a method for characterizing brand value, and felt that the obligation of promoting must be to expand brand loyalty. Blackston noticed that minority of clients represented the greater part of offers. Blackston referred to the general accord of the 20/80 rule, utilized as a dependable guideline, which expresses that $20 \%$ of the client's record for $80 \%$ of offers volume. Blackston's thinking was that the target of expanding brand dedication fell on publicizing duplicate. He additionally characterized a brand faithful client as one whose rate of class necessities filled by that brand was more noteworthy than the normal rate of prerequisites filled by the normal brand for a similar classification.

Dyson, Farr, and Hollis (1996) concentrate the approach of measuring brand value. They built up the Consumer Value model to put money related added value on brand value. This model anticipated the percent of a person's classification that went to each brand in the classification. The model at that point connected the measure of brand faithfulness to esteem. To clarify variety among buyers (Dyson et al., 1996) utilized the Brand Dynamics Trademark Pyramid, which measures the levels of brand loyalty as significance, execution, advantage, and fortified. The fortified level started with $38 \%$ of class use on a specific 
brand. This upheld Blackston's meaning of brand faithfulness.

Creyer and Ross (1997) examined buyer responses to brand esteem classification. They considered standard quality estimations and an esteem list. Creyer and Ross found that when purchasers were given data on cost and quality per dollar, they chose bring down costs and higher esteem brands. At the point when given data on costs and quality evaluations, customers chose the higher cost and higher quality brands. Expanded data seemed to perplex the determination procedure in this review, the idea of pertinent cost or worth recognition was presented by Grewal, Monroe, and Krishnan (1998). They built a model from earlier models to show connections between quality, cost, perceived cost, and perceived esteem. They utilized Rajendran and Tellis (1994)'s idea of reference value, which included promoting signals on purchasers' inside reference cost and (Zeithaml, 1988)'s idea of perceived quality, which was operationalized as customer's reference cost.

Ehrenberg, Goodhardt, and Barwise (1990) tended to the twofold peril issue by clarifying the arithmetic of the twofold danger burdens that low piece of the overall industry brands had on deals, both in numbers and utilization per buy among their clients. They additionally noticed that this idea did not hold in uncommon fragments or specialty brands. Baldinger and Rubinson (1997) built up another twofold danger viewpoint; low piece of the overall industry brands had a tendency to have bring down market infiltration rates, and lower buy rates. Purchasers who were additionally faithful to a contender were destined to change to the brand that they supported, attitudinally. Brands with low extents of very brand steadfast customers, having solid mentalities, had a tendency to lose these exceptionally mark faithful purchasers at a higher rate after some time.

Grewal et al. (1998) additionally concentrated the impacts of these connections on undergrads' purchase goals of bikes. They discovered positive connections between quality observations and worth recognitions, between promoted offering costs and worth discernments, between publicized reference costs and worth recognitions, between quality discernments and perceived procurement esteems, between publicized costs and perceived securing values, and between perceived obtaining qualities and ability to buy.

Mulhern and Padgett (1995) concentrated the connection between retail value advancements and normal value buys of various items or brands. Purchases of various items or brands were contemplations of responses to transitory value decreases. They utilized an expansive example from a fair sized metropolitan range for home change items. As a foundation for thinking for brief value 40 diminishments, Jeuland and Narasimhan (1985) broke down impermanent value bargains and built up a model of value separation for purchasers of various value sensitivities. Jeuland and Narasimhan (1985) reasoned that specific purchasers were cost inclined and would react to advancements and would stockpile, non-cost inclined purchasers, then again, would not. Non-cost inclined purchasers tended to shop at the retail foundation paying to the presence of an advancement and cost inclined purchasers will probably shop at the store for obtaining advanced items. So also, Varian (1980)'s hypothesis on contrasts in shopper data clarifies the behavioural contrasts amongst educated and clueless purchasers. While clueless shoppers picked a store indiscriminately, educated customers knew the appropriation of costs and contenders' conveyances of costs, and acted in like manner.

Derbaix (1995) concentrated the criticalness of earlier brand information and its im- 
pacts on publicizing states of mind, and additionally approaches to quantify those impacts. Earlier brand information and states of mind were viewed as imperative without real brand involvement. Full of feeling reactions from the promotion could likewise, once in a while, influence mentality toward the brand (Stayman \& Aaker, 1988; Derbaix, 1995) and sentiments created by publicizing influenced both disposition toward publicizing and state of mind toward the brand (Burke \& Edell, 1989; Derbaix, 1995). These disposition arrangement coordinated toward publicizing was essential since promoting achieved the consideration of the non-shopper and additionally the current customer.

Figure 1

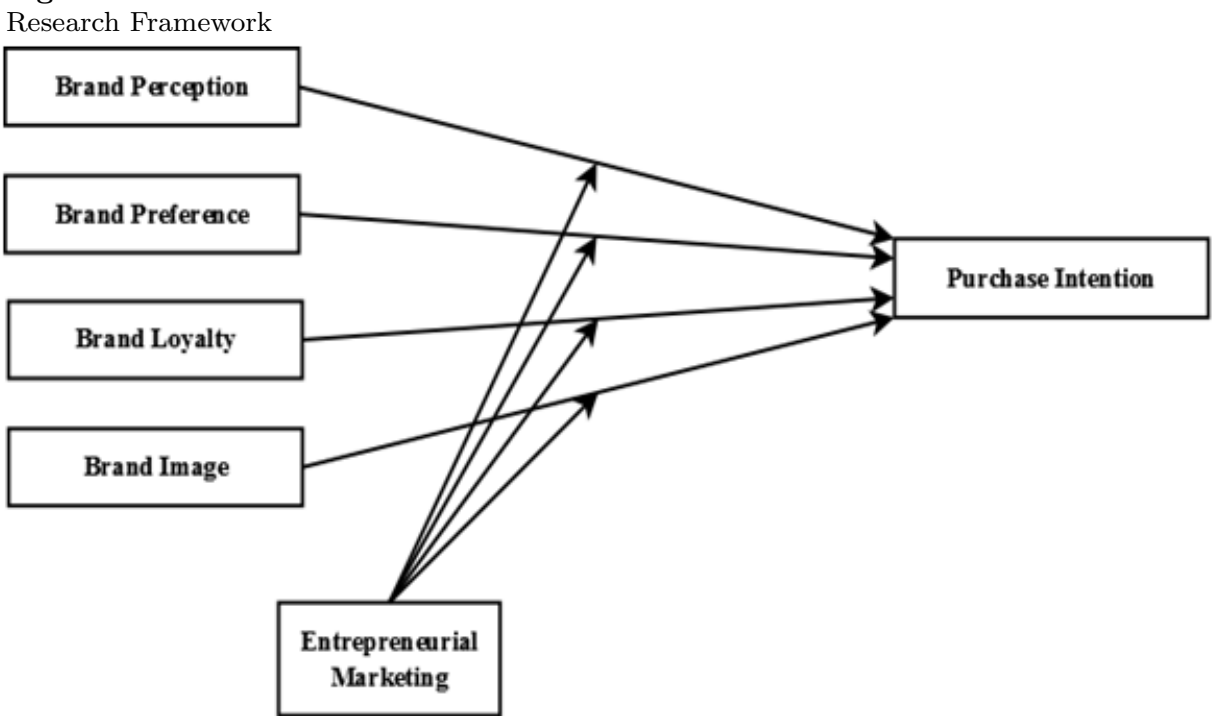

\section{Methodology}

The study has used quantitative explanatory research design. In this concern, a sample of 424 responses was collected using convenience sampling technique from different self-service stores and mega malls of Karachi city, Pakistan. According to Creswell and Tashakkori (2007), the better the sample size of the research the better and concrete would be the results. Among the initially distributed 450 questionnaires, 445 returns from the respondents, whereas, only 438 questionnaires were included in the study for data analysis, however, remaining 7 questionnaires were discarded due to non-serious responses. Survey questionnaire was adopted from numerous past studies. The items of brand perception has been adopted from Ebrahim (2013), brand preference from Mahfooz (2015) and Soenyoto (2015), brand loyalty from Mahfooz (2015) and Nigam and Kaushik (2011), brand image from Ling, Lang, Fong, and Perinpajothi (2014), entrepreneurial marketing from Kilenthong et al. (2015) and purchase intention from Mahfooz (2015), Soenyoto (2015) and Hanzaee and Rouhani (2013). The questionnaire was based on five-point Likert 
measurement scale follows $1=$ strongly disagree and $5=$ strongly agree.

\section{Data Analysis}

\section{Demographics of the Respondents}

Demographic statistics of the respondents participated in the study have been shown in the following table 1 .

Table1

Demographic Statistics

\begin{tabular}{llcc}
\hline & & Frequency & Percent \\
\hline \multirow{3}{*}{ Gender } & Male & 201 & 45.9 \\
& Female & 237 & 54.1 \\
\hline \multirow{2}{*}{ Marital Status } & Single & 233 & 53.2 \\
& Married & 205 & 46.8 \\
\hline \multirow{5}{*}{ Age Group } & $20-29$ years & 164 & 37.4 \\
& $30-39$ years & 217 & 49.5 \\
& $40-49$ years & 34 & 7.8 \\
& 50 years \& above & 23 & 5.3 \\
\hline \multirow{5}{*}{ Academic Qualification } & Bachelors & 222 & 50.7 \\
& Master & 177 & 40.4 \\
& MPhil/PhD & 18 & 4.1 \\
& Others & 21 & 4.8 \\
\hline \multirow{3}{*}{ Occupation } & Self-Employed & 37 & 8.4 \\
& Employed & 225 & 51.4 \\
& Student & 176 & 40.2 \\
\hline
\end{tabular}

\section{Construct Validity}

The study has considered construct validity to be achieved at factor loadings greater than 0.60 and should have statistically significant at 95 percent confidence interval. These statistical thresholds for PLS-SEM were proposed by Hair Jr, Sarstedt, Hopkins, and Kuppelwieser (2014). In this concern, the following table 2 shows the result of construct validity.

It has been clearly shown in the above table that all the factors were loaded at greater coefficients than 0.60 threshold value and significant at 95 percent confidence interval. Hence, constructs validity has been achieved for the study.

\section{Convergent Validity}

In regards to convergent validity, the study has used three basic and general parameters for convergence estimation among the measures of particular variable. These parameters for convergence estimation include Cronbach's Alpha reliability analysis, composite reliability and average variance extracted, as suggested by Nunnally (1967). For these estimation, it has been established by that alpha coefficient should be greater than 0.60 , whereas, Hair Jr et al. (2014) suggested that composite reliability should be greater than 0.70 and average variance extracted should be at least 0.50 or higher. The following table 3 shows estimation of convergent validity. 
Table 2

Construct Validity

\begin{tabular}{|c|c|c|c|}
\hline Variable & Measures & Estimate & P Values \\
\hline \multirow{7}{*}{ Entrepreneurial Marketing } & EM1 & 0.804 & 0.000 \\
\hline & EM2 & 0.780 & 0.000 \\
\hline & EM3 & 0.825 & 0.000 \\
\hline & EM4 & 0.856 & 0.000 \\
\hline & EM5 & 0.786 & 0.000 \\
\hline & EM6 & 0.759 & 0.000 \\
\hline & EM7 & 0.799 & 0.000 \\
\hline \multirow{5}{*}{ Brand Image } & Image1 & 0.888 & 0.000 \\
\hline & Image2 & 0.894 & 0.000 \\
\hline & Image3 & 0.877 & 0.000 \\
\hline & Image4 & 0.891 & 0.000 \\
\hline & Image5 & 0.898 & 0.000 \\
\hline \multirow{5}{*}{ Brand Loyalty } & Loyalty1 & 0.864 & 0.000 \\
\hline & Loyalty2 & 0.872 & 0.000 \\
\hline & Loyalty3 & 0.633 & 0.000 \\
\hline & Loyalty4 & 0.784 & 0.000 \\
\hline & Loyalty5 & 0.770 & 0.000 \\
\hline \multirow{5}{*}{ Brand Perception } & Perception1 & 0.861 & 0.000 \\
\hline & Perception2 & 0.860 & 0.000 \\
\hline & Perception3 & 0.891 & 0.000 \\
\hline & Perception4 & 0.908 & 0.000 \\
\hline & Perception5 & 0.880 & 0.000 \\
\hline \multirow{6}{*}{ Brand Preference } & Preference1 & 0.762 & 0.000 \\
\hline & Preference2 & 0.748 & 0.000 \\
\hline & Preference3 & 0.802 & 0.000 \\
\hline & Preference4 & 0.707 & 0.000 \\
\hline & Preference 5 & 0.671 & 0.000 \\
\hline & Preference6 & 0.631 & 0.000 \\
\hline \multirow{5}{*}{ Purchase Intention } & Purchase_Intention1 & 0.724 & 0.000 \\
\hline & Purchase_Intention2 & 0.789 & 0.000 \\
\hline & Purchase_Intention3 & 0.824 & 0.000 \\
\hline & Purchase_Intention4 & 0.797 & 0.000 \\
\hline & Purchase_Intention5 & 0.611 & 0.000 \\
\hline
\end{tabular}

Table 3

Convergent Validity

\begin{tabular}{lccc}
\hline Variables & $\begin{array}{c}\text { Cronbach's } \\
\text { Alpha }\end{array}$ & $\begin{array}{c}\text { Composite } \\
\text { Reliability }\end{array}$ & $\begin{array}{c}\text { Average Variance } \\
\text { Extracted (AVE) }\end{array}$ \\
\hline Brand Image & 0.935 & 0.950 & 0.792 \\
Brand Loyalty & 0.846 & 0.891 & 0.623 \\
Brand Perception & 0.927 & 0.945 & 0.775 \\
Brand Preference & 0.822 & 0.867 & 0.522 \\
Entrepreneurial Marketing & 0.909 & 0.926 & 0.643 \\
Purchase Intention & 0.806 & 0.866 & 0.567 \\
\hline
\end{tabular}

Table 3 established that the study has successfully achieved convergent validity. All the three parameters for convergence estimation amongst variable have met suggested thresholds. Hence, the measures of each variable have considerable reliability and explain its particular variable adequately. 


\section{Discriminant Validity}

In PLS-SEM, discriminant validity can assess by three different techniques essentially required for comprehensive estimation of required discrimination and differences amongst the study variables. In this concern, Fornell and Larcker (1981a) criterion, cross-loadings, and Heterotrait-Monotrait (HTMT) ratio were particularly employed in the study. Table 4 shows result of Fornell and Larcker (1981a, 1981b) criterion and its estimation criterion includes that square-root of AVE to each variable should have greater than its respective vertical values.

Table 4

Fornell and Larcker Criterion

\begin{tabular}{lllllll}
\hline & BIMAGE & BLOYAL & BPERC & BPREF & EM & PI \\
\hline Brand Image & $\mathbf{0 . 8 9 0}$ & & & & & \\
Brand Loyalty & 0.101 & $\mathbf{0 . 7 8 9}$ & & & & \\
Brand Perception & 0.236 & 0.201 & $\mathbf{0 . 8 8 0}$ & & & \\
Brand Preference & -0.012 & 0.304 & -0.135 & $\mathbf{0 . 7 2 2}$ & & \\
Entrepreneurial Marketing & 0.025 & 0.200 & 0.274 & -0.164 & $\mathbf{0 . 8 0 2}$ & \\
Purchase Intention & 0.093 & 0.483 & 0.205 & 0.253 & 0.141 & $\mathbf{0 . 7 5 3}$ \\
\hline
\end{tabular}

Foremost importantly, the Fornell and Larcker criterion for discriminant validity has been achieved adequately as all the variables have greater square-rooted AVE in respect to its corresponding variables. Moreover, table 5 shows estimation of HTMT ratio for discrimination validity. It has the threshold of less than 0.85 , as suggested by Henseler, Ringle, and Sarstedt (2015).

Table 5

Heterotrait-Monotrait (HTMT) Ratio

\begin{tabular}{|c|c|c|c|c|c|c|}
\hline & BIMAGE & BLOYAL & BPERC & BPREF & EM & PI \\
\hline \multicolumn{7}{|l|}{ Brand Image } \\
\hline Brand Loyalty & 0.105 & & & & & \\
\hline Brand Perception & 0.250 & 0.225 & & & & \\
\hline Brand Preference & 0.073 & 0.340 & 0.195 & & & \\
\hline Entrepreneurial Marketing & 0.050 & 0.226 & 0.293 & 0.251 & & \\
\hline Purchase Intention & 0.105 & 0.567 & 0.237 & 0.285 & 0.174 & \\
\hline
\end{tabular}

HTMT ratio is an advance statistical technique that helps to assess discriminant validity amongst variables in PLS-SEM, as shown in the above table. It has clearly shown that all the variables significantly distinct in their domains. The suggested threshold was considered that all the variables have less than 0.85 coefficients in HTMT ratio for achieving adequate discriminant validity (Henseler et al., 2015). Therefore, it has been achieved appropriately for the current study. Lastly, table 6 shows cross-loadings amongst all the variables and it helps to validate discrimination amongst variables by providing that each factor loading of the measure to its respective variable have greater value than its loading to any other variable. This helps to identify and highlight statistical differences in each factor loaded in any particular variable. 
Table 6

\begin{tabular}{|c|c|c|c|c|c|c|}
\hline & BIMAGE & BLOYAL & BPERC & BPREF & EM & PI \\
\hline EM1 & -0.012 & 0.195 & 0.262 & -0.169 & 0.804 & 0.098 \\
\hline EM2 & 0.010 & 0.171 & 0.241 & -0.219 & 0.780 & 0.066 \\
\hline EM3 & -0.022 & 0.154 & 0.253 & -0.106 & 0.825 & 0.149 \\
\hline EM4 & 0.059 & 0.180 & 0.214 & -0.126 & 0.856 & 0.132 \\
\hline EM5 & 0.074 & 0.165 & 0.224 & -0.115 & 0.786 & 0.120 \\
\hline EM6 & -0.029 & 0.133 & 0.157 & -0.105 & 0.759 & 0.058 \\
\hline EM7 & 0.037 & 0.127 & 0.169 & -0.128 & 0.799 & 0.109 \\
\hline Image1 & 0.888 & 0.055 & 0.224 & -0.010 & 0.036 & 0.081 \\
\hline Image2 & 0.894 & 0.086 & 0.179 & -0.010 & 0.004 & 0.066 \\
\hline Image3 & 0.877 & 0.073 & 0.203 & 0.006 & 0.017 & 0.074 \\
\hline Image4 & 0.891 & 0.092 & 0.213 & -0.028 & 0.017 & 0.087 \\
\hline Image5 & 0.898 & 0.130 & 0.222 & -0.008 & 0.033 & 0.099 \\
\hline Loyalty1 & 0.139 & 0.864 & 0.174 & 0.311 & 0.168 & 0.479 \\
\hline Loyalty2 & 0.097 & 0.872 & 0.167 & 0.242 & 0.141 & 0.378 \\
\hline Loyalty3 & 0.059 & 0.633 & 0.138 & 0.142 & 0.112 & 0.269 \\
\hline Loyalty4 & 0.019 & 0.784 & 0.082 & 0.196 & 0.165 & 0.357 \\
\hline Loyalty5 & 0.062 & 0.770 & 0.225 & 0.272 & 0.196 & 0.383 \\
\hline Perception1 & 0.210 & 0.180 & 0.861 & -0.081 & 0.212 & 0.180 \\
\hline Perception2 & 0.185 & 0.164 & 0.860 & -0.103 & 0.208 & 0.163 \\
\hline Perception3 & 0.228 & 0.155 & 0.891 & -0.172 & 0.234 & 0.186 \\
\hline Perception4 & 0.191 & 0.190 & 0.908 & -0.124 & 0.274 & 0.169 \\
\hline Perception5 & 0.220 & 0.192 & 0.880 & -0.110 & 0.271 & 0.202 \\
\hline Preference1 & -0.005 & 0.159 & -0.128 & 0.762 & -0.136 & 0.191 \\
\hline Preference2 & -0.071 & 0.145 & -0.303 & 0.748 & -0.266 & 0.121 \\
\hline Preference3 & -0.084 & 0.183 & -0.193 & 0.802 & -0.205 & 0.143 \\
\hline Preference4 & 0.027 & 0.247 & -0.058 & 0.707 & -0.135 & 0.179 \\
\hline Preference5 & -0.020 & 0.255 & -0.030 & 0.671 & -0.146 & 0.104 \\
\hline Preference6 & 0.042 & 0.277 & 0.028 & 0.631 & 0.041 & 0.253 \\
\hline Purchase_Intention1 & 0.066 & 0.264 & 0.100 & 0.190 & 0.178 & 0.724 \\
\hline Purchase_Intention2 & 0.050 & 0.350 & 0.233 & 0.116 & 0.193 & 0.789 \\
\hline Purchase_Intention3 & 0.078 & 0.427 & 0.143 & 0.203 & 0.079 & 0.824 \\
\hline Purchase_Intention4 & 0.085 & 0.402 & 0.085 & 0.285 & 0.019 & 0.797 \\
\hline Purchase_Intention5 & 0.069 & 0.346 & 0.212 & 0.147 & 0.088 & 0.611 \\
\hline
\end{tabular}

It has been clearly shown in the above table that all the factors have higher loadings in their particular variables as compare to their cross-loadings to other variables. Hence, the study has achieved discriminant validity through cross-loadings as well.

\section{Path Analysis}

Following table 7 shows path analysis of the structural model. It has been estimated using SmartPLS software at 5 percent significance level. 


\section{Figure 2}

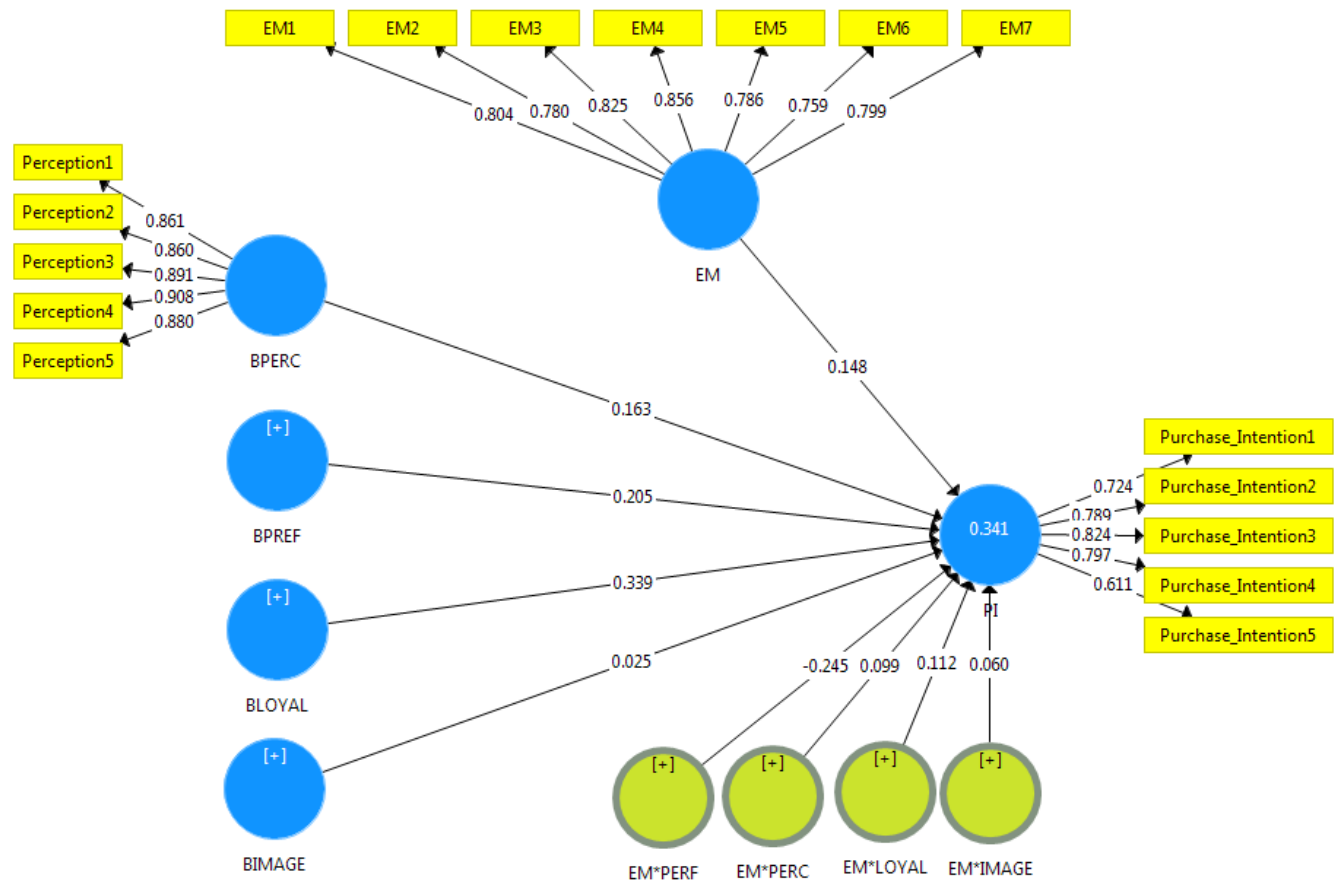

Table 7

Path Analysis

\begin{tabular}{|c|c|c|c|c|c|}
\hline & Estimate & S.E. & T-Stats & Sig. & Remarks \\
\hline Brand Image $\rightarrow$ Purchase Intention & 0.025 & 0.042 & 0.584 & 0.559 & Not Supported \\
\hline Brand Loyalty $\rightarrow$ Purchase Intention & 0.339 & 0.067 & 5.095 & 0.000 & Supported \\
\hline Brand Perception $\rightarrow$ Purchase Intention & 0.163 & 0.052 & 3.147 & 0.002 & Supported \\
\hline Brand Preference $\rightarrow$ Purchase Intention & 0.205 & 0.052 & 3.979 & 0.000 & Supported \\
\hline Entrepreneurial Marketing*Brand Image $\rightarrow$ Purchase Intention & 0.060 & 0.053 & 1.147 & 0.252 & Not Supported \\
\hline Entrepreneurial Marketing*Brand Loyalty $\rightarrow$ Purchase Intention & 0.112 & 0.044 & 2.539 & 0.011 & Supported \\
\hline Entrepreneurial Marketing*Brand Perception $\rightarrow$ Purchase Intention & 0.099 & 0.043 & 2.275 & 0.023 & Supported \\
\hline Entrepreneurial Marketing*Brand Preference $\rightarrow$ Purchase Intention & -0.245 & 0.056 & 4.357 & 0.000 & Supported \\
\hline
\end{tabular}

It has been shown in the above table that brand loyalty $(0.339, \mathrm{p}<0.001)$, brand perception $(0.163, \mathrm{p}<0.01)$ and brand preference $(0.205, \mathrm{p}<0.001)$ have statistically significant and positive impact on purchase intention. Among the three statistically significant variables, brand loyalty has most impact on purchase intention, followed by brand preference and least influenced by brand perception. Additionally, the results showed that entrepreneurial marketing moderates the relationship of brand loyalty $(0.112, \mathrm{p}<0.05)$, brand perception $(0.099, \mathrm{p}<0.05)$ and brand preference $(-0.245, \mathrm{p}<0.001)$ with purchase intentions of consumer toward FMCG brands in Pakistan. However, the results interestingly showed that brand image $(0.025, \mathrm{p}>0.10)$ does not influence purchase intention and 
also, entrepreneurial marketing does not moderate its relationship with purchase intention $(0.060, \mathrm{p}>0.10)$ in regards to FMCG brands in Pakistan. The study also showed that combination of all the variables has strength to predict 34.1 percent of purchase intention in regards to FMCG brands of Pakistan.

Figure 3

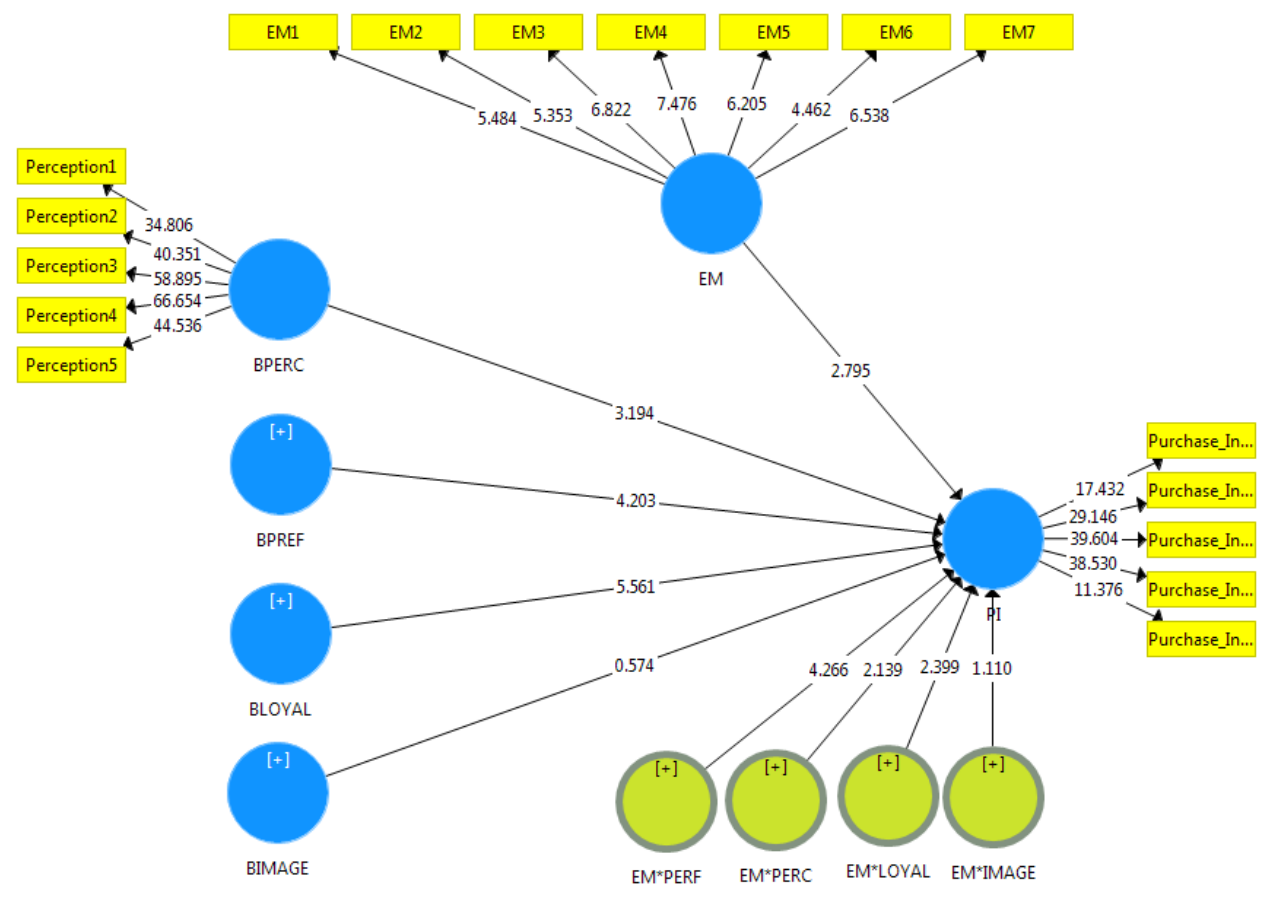

The results have shown that brand loyalty, brand perception and brand preference have positive and significant influence on the consumers' intention to purchase FMCG brands in Karachi, Pakistan. These results found consistent with the results and findings of the past studies including (Mahfooz, 2015), (Nigam \& Kaushik, 2011) and (Ling et al., 2014). These components of brand equity has been playing significantly positive role in the purchase decision process of the consumers regards FMCG brands in Karachi, Pakistan.

In regards to insignificant impact of brand image on the purchase intention of consumers in Karachi, Pakistan, (Li, Huanyong, \& Jiang, 2013) has found consistent. It provided that brand image may be insignificant due to weak perceived quality of the brand that leads to insignificant impact of brand image on the purcahse intention of consumers (Li et al., 2013).

In Niazi, Ghani, and Aziz (2012) and Cobb-Walgren et al. (1995), it has been shown that brand preference have statistically positive association with the purchase intention of the consumers. Due to strong perception generated from massive advertising campaign 
from the FMCG companies of Pakistan, it strengthens brand equity resulting towards positive perception of the brand in consumers' mind (Niazi et al., 2012) and (Cobb-Walgren et al., 1995). Surprisingly, the results and findings showed that entrepreneurial marketing moderates the relationship between independent variables and purchase intention. Therefore, it has been to be taken seriously in regards to accomplish marketing objectives and achieve better organizational outcomes.

\section{Conclusion and Recommendations}

The study investigated four brand equity drivers for consumers' purchase intention towards FMCG brands in Karachi, Pakistan. These drivers include brand perception, brand preference, brand image and brand loyalty. The results and findings clearly showed that brand loyalty, brand perception and brand preference have contributed significantly to purchase intention of consumers toward FMCG brands in Pakistan. However, brand image does not have any influence on consumers' purchase intention. Although, the moderating effect of entrepreneurial marketing showed constructive outcomes except for the relationship between brand image and purchase intention in Karachi, Pakistan. Similarly, past literatures examined the relationship between brand image and purchase intention (Wu, Yeh, \& Hsiao, 2011; Shah et al., 2012; Chen \& Chang, 2008; Diamantopoulos, Schlegelmilch, \& Palihawadana, 2011). Wu et al. (2011); Shah et al. (2012) found brand image has significant effect on purchase intention which shows that private label brands create their brand image by attaching unique association to the quality of their service. Moreover, Chen and Chang (2008); Diamantopoulos et al. (2011), found brand image has significant effect on purchase intention.

In this concern, it has been clearly shown by the results that, except brand image, all three variables contributed enormously to purchase intention of consumers in Karachi in regards to FMCG brands. Therefore, it has been critically important for the companies to concentrates further on building brand perception and brand preference through various tactical and strategic manifestations of marketing and promotion policies. However, FMCG companies must have to strive hard for appropriate entrepreneurial marketing strategy. Though, the results and findings showed some declining patterns in brand loyalty, perception and preferences, these technical methodologies must have taken seriously for fruitful outcomes and brand building.

In this regards, the study suggests some managerial recommendations to FMCG companies in Pakistan for improving their marketing and promotion strategies.FMCG companies of Pakistan should focus mainly on improving and enhancing their brand loyalty. Specific and positively ethical advertising campaigns should also facilitate the companies' marketing plan to enhance their brand in the mind of consumers. Further, appropriate and timely communication with the customers and also involving them into certain marketing campaigns also facilitate FMCG companies to improve their brand loyalty. Also, adequate brand extension strategy should also facilitate the consumers to increase their level of loyalty with the FMCG brands. Past literatures shows the same results (Malik et al., 2013; Chi, Yeh, \& Yang, 2009). Similarly, Malik et al. (2013), found the brand loyalty has a 
significant effect on customer purchase intention which shows that the brand loyalty is very important for the organization, as it plays an important role in making its customers happy and also resolve the problems if they feel to buy during purchase of particular product and service. Also, Chi et al. (2009), found that brand loyalty has a significant effect on customer purchase intention.

However, improving brand perception and preference through positive word of mouth and appropriate social media strategy should also be taken into consideration by the FMCG companies of Pakistan. It can also be achieved by enhancing the service and product quality and it assists them into more conscious and serious behavior towards their purchase intention. Moreover, past literatures shows the same results, (Hung et al., 2011; Rafique, 2012; Hooten, Noeva, \& Hammonds, 2009; Sari \& Kusuma, 2014), that the brand perception has significant impact on purchase intention which means that brand perceptions involves the functional, experiential and symbolic values of customers' which influence them to purchase brands. Furthermore, study results show that brand preference has significant impact on purchase intention which means preference increases customers' brand consciousness for buying well-known branded products. However, past literatures shows the same results, (Lee, Kim, Pelton, Knight, \& Forney, 2008; Jin \& Gu Suh, 2005; Cobb-Walgren et al., 1995; Chen \& Chang, 2008).

\section{Perception and Preference}

There are majorly few limitations to research include sample size, sampling technique, statistical technique and some limitation to time and resources causes the study to establish less generalized results and findings. Moreover, the limitation of statistical technique as due to lack of sample data and diversified FMCG brands, as focused by the study, the complex models were not taken into consideration to simply the results and findings. Therefore, the study recommends that brand equity components have been investigated towards the FMCG brands in Karachi, Pakistan as influencing factors on the purchase intention of consumers. Moreover, increasing sample size and more specific probability sampling technique has to be employed in the future studies to improve the generalizability of results and findings of the future researches. Additionally, other major cities of Pakistan should also be included in the future studies. However, challenges and issues related to the implementation of brand equity and consumers' purchase intention would also be profoundly beneficial horizon for future studies. 


\section{References}

Aaker, D. (1991). Brand equity. La Gestione Del Valore Della Marca, 347-356.

Aaker, D. A. (1996). Measuring brand equity across products and markets. California Management Review, 38(3), 102-120.

Aaker, J., \& Fournier, S. (1995). A brand as a character, a partner and a person: Three perspectives on the question of brand personality. ACR North American Advances.

Aaker, J. L. (1997). Dimensions of brand personality. Journal of Marketing Research, $34(3), 347-356$.

Austin, J. R., Siguaw, J. A., \& Mattila, A. S. (2003). A re-examination of the generalizability of the Aaker brand personality measurement framework. Journal of Strategic Marketing, $11(2), 77-92$.

Baldinger, A. L., \& Rubinson, J. (1997). The jeopardy in double jeopardy. Journal of Advertising Research, 37(6), 37-50.

Becherer, R. C., \& Helms, M. M. (2016). The role of entrepreneurial marketing in improving market share for small businesses facing external environmental or resource challenges. Journal of Business and Entrepreneurship, 27(2), 119-147.

Berthon, P. R., Pitt, L., Parent, M., \& Berthon, J.-P. (2009). Aesthetics and ephemerality: Observing and preserving the luxury brand. California Management Review, 52(1), 45-66.

Blackston, M. (1995). The qualitative dimension of brand equity. Journal of Advertising Research, 35(4), RC2-RC7.

Burke, M. C., \& Edell, J. A. (1989). The impact of feelings on ad-based affect and cognition. Journal of Marketing Research, 69-83.

Carson, D. (1990). Some exploratory models for assessing small firms' marketing performance (A qualitative approach). European Journal of Marketing, 24(11), 8-51.

Chaston, I. (1997). How interaction between relationship and entrepreneurial marketing may affect organizational competencies in small UK manufacturing firms. Marketing Education Review, 7(3), 55-65.

Chen, C. F., \& Chang, Y. Y. (2008). Airline brand equity, brand preference, and purchase intentions: The moderating effects of switching costs. Journal of Air Transport Management, 14(1), 40-42.

Chi, H. K., Yeh, H. R., \& Yang, Y. T. (2009). The impact of brand awareness on consumer purchase intention: The mediating effect of perceived quality and brand loyalty. The Journal of International Management Studies, 4(1), 135-144.

Cobb-Walgren, C. J., Ruble, C. A., \& Donthu, N. (1995). Brand equity, brand preference, and purchase intent. Journal of Advertising, 24(3), 25-40.

Creswell, J. W., \& Tashakkori, A. (2007). Differing perspectives on mixed methods research. Sage Publications Sage CA: Los Angeles, CA.

Creyer, E. H., \& Ross, W. T. (1997). Tradeoffs between price and quality: How a value index affects. Journal of Consumer Affairs, 31(2), 280-302.

Dennis, C., Papagiannidis, S., Alamanos, E., \& Bourlakis, M. (2017). The Role of Brand Attachment and Its Antecedents in Brand Equity in Higher Education. Springer, Cham. 
Derbaix, C. M. (1995). The impact of affective reactions on attitudes toward the advertisement and the brand: A step toward ecological validity. Journal of marketing research, 32(4), 470-479.

Diamantopoulos, A., Schlegelmilch, B., \& Palihawadana, D. (2011). The relationship between country-of-origin image and brand image as drivers of purchase intentions: A test of alternative perspectives. International Marketing Review, 28(5), 508-524.

Dyson, P., Farr, A., \& Hollis, N. S. (1996). Understanding, measuring, and using brand equity. Journal of Advertising Research, 36(6), 9-22.

Ebrahim, R. (2013). A study of brand preference: An experiential view. London: Brunel Business School.

Ehrenberg, A. S., Goodhardt, G. J., \& Barwise, T. P. (1990). Double jeopardy revisited. The Journal of Marketing, 54(3), 82-91.

Elvira, F.-B., \& Xhaferi-Elona, F. (2014). The spontaneity of international market and the need for entrepreneurial marketing evidence of albanian entrepreneurs in italy. Business Management Dynamics, 3(10), 14-20.

Farquhar, P. H. (1989). Managing brand equity. Marketing Research, 1(3), 24-33.

Fornell, C., \& Larcker, D. F. (1981a). Evaluating structural equation models with unobservable variables and measurement error. Journal of Marketing Research, 18(1), $39-50$.

Fornell, C., \& Larcker, D. F. (1981b). Structural equation models with unobservable variables and measurement error: Algebra and statistics. Journal of Marketing Research, $18(3), 382-388$.

Franco, M., de Fátima Santos, M., Ramalho, I., \& Nunes, C. (2014). An exploratory study of entrepreneurial marketing in SMEs: The role of the founder-entrepreneur. Journal of Small Business and Enterprise Development, 21 (2), 265-283.

Gardner, B. B., \& Levy, S. J. (1963). The product and the brand. RD Irwin.

Gilmore, A., \& Carson, D. (1999). Entrepreneurial marketing by networking. New England Journal of Entrepreneurship, 2(2), 31.

Grewal, D., Monroe, K. B., \& Krishnan, R. (1998). The effects of price-comparison advertising on buyers' perceptions of acquisition value, transaction value, and behavioral intentions. The Journal of Marketing, 62(2), 46-59.

Grohmann, B., Giese, J. L., \& Parkman, I. D. (2013). Using type font characteristics to communicate brand personality of new brands. Journal of Brand Management, 20(5), 389-403.

Gürhan-Canli, Z., Hayran, C., \& Sarial-Abi, G. (2016). Customer-based brand equity in a technologically fast-paced, connected, and constrained environment. AMS review, $6(1-2), 23-32$.

Hair Jr, J., Sarstedt, M., Hopkins, L., \& Kuppelwieser, V. (2014). Partial least squares structural equation modeling (pls-sem) an emerging tool in business research. European Business Review, 26(2), 106-121.

Hanzaee, K., \& Rouhani, F. (2013). Investigation of the effects of luxury brand perception and brand preference on purchase intention of luxury products. African Journal of Business Management, 7(18), 1778-1790. 
Henseler, J., Ringle, C. M., \& Sarstedt, M. (2015). A new criterion for assessing discriminant validity in variance-based structural equation modeling. Journal of the Academy of Marketing Science, 43(1), 115-135.

Hernández-Perlines, F. (2016). Entrepreneurial orientation in hotel industry: Multi-group analysis of quality certification. Journal of Business Research, 69(10), 4714-4724.

Hills, G. E., Hultman, C. M., \& Miles, M. P. (2008). The evolution and development of entrepreneurial marketing. Journal of Small Business Management, 46(1), 99-112.

Hooten, M. A., Noeva, K., \& Hammonds, F. (2009). The effects of homosexual imagery in advertisements on brand perception and purchase intention. Social Behavior and Personality: An International Journal, 37(9), 1231-1238.

Hung, K. P., Huiling Chen, A., Peng, N., Hackley, C., Amy Tiwsakul, R., \& Chou, C. l. (2011). Antecedents of luxury brand purchase intention. Journal of Product \& Brand Management, 20(6), 457-467.

Iglesias, O., Markovic, S., Singh, J. J., \& Sierra, V. (2017). Do customer perceptions of corporate services brand ethicality improve brand equity? Considering the roles of brand heritage, brand image, and recognition benefits. Journal of Business Ethics, 1-19. doi: DOI10.1007/s10551-017-3455-0

Jacoby, J., Chestnut, R. W., \& Fisher, W. A. (1978). A behavioral process approach to information acquisition in nondurable purchasing. Journal of Marketing Research, $15(4), 532-544$.

Janet, M., \& Ngugi, K. (2014). Influence of entrepreneurial marketing on the growth of smes in Kiambu Town-CBD, Kenya. European Journal of Business Management, 1(11), 361-377.

Jeuland, A. P., \& Narasimhan, C. (1985). Dealing-temporary price cuts-by seller as a buyer discrimination mechanism. Journal osf Business, 58(3), 295-308.

Jin, B., \& Gu Suh, Y. (2005). Integrating effect of consumer perception factors in predicting private brand purchase in a Korean discount store context. Journal of Consumer Marketing, 22(2), 62-71.

Keller, K. L. (1993). Conceptualizing, measuring, and managing customer-based brand equity. the Journal of Marketing, 57(1), 1-22.

Keller, K. L., \& Lehmann, D. R. (2003). How do brands create value? Marketing Management, 12(3), 26-31.

Kilenthong, P., Hills, G. E., \& Hultman, C. M. (2015). An empirical investigation of entrepreneurial marketing dimensions. Journal of International Marketing Strategy, 3(1), 1-18.

Koren, Y., Wang, W., \& Gu, X. (2017). Value creation through design for scalability of reconfigurable manufacturing systems. International Journal of Production Research, $55(5), 1227-1242$.

Kotler, P., \& Armstrong, G. (2010). Principles of marketing. Pearson education.

Kowalik, I., \& Duliniec, E. (2015). The entrepreneurial marketing concept and its application by the international new ventures'. Chinese Business Review, 14(5), 253-264.

Lassar, W., Mittal, B., \& Sharma, A. (1995). Measuring customer-based brand equity. Journal of Consumer Marketing, 12(4), 11-19.

Lee, M. Y., Kim, Y. K., Pelton, L., Knight, D., \& Forney, J. (2008). Factors affecting 
mexican college students' purchase intention toward a US apparel brand. Journal of Fashion Marketing and Management: An International Journal, 12(3), 294-307.

Li, J., Huanyong, J., \& Jiang, L. (2013). The influence of brand perception on the perceived quality: An emperical study in China. Pakistan Journal of Statistics, 29(6), 9991017.

Ling, L., Lang, P., Fong, T., \& Perinpajothi, T. (2014). Factors affecting purchase intention towards smartphone brand: A study of young female adult consumers (Unpublished doctoral dissertation). (Doctoral dissertation, UTAR).

Mahfooz, Y. (2015). Brand equity-consequence relationship: Evidence from automobile industry. International Journal of Business and Management, 10(3), 81-90.

Malik, M. E., Ghafoor, M. M., Hafiz, K. I., Riaz, U., Hassan, N. U., Mustafa, M., \& Shahbaz, S. (2013). Importance of brand awareness and brand loyalty in assessing purchase intentions of consumer. International Journal of Business and Social Science, 4(5), 167-171.

Marquardt, A. J., Kahle, L. R., O'Connell, D. P., \& Godek, J. (2017). LOV measures: Using the list of values to measure symbolic brand equity (An Abstract). Springer, Cham.

Martin, S. L., \& Javalgi, R. R. G. (2016). Entrepreneurial orientation, marketing capabilities and performance: The moderating role of competitive intensity on latin american international new ventures. Journal of Business Research, 69(6), 2040-2051.

Martins, A., Martins, I., \& Pereira, O. (2017). Embracing innovation and creativity through the capacity of unlearning. Handbook of Research on Human Resources Strategies for the New Millennial Workforce, 128-147.

Menon, V. P., \& Barani, G. (2016). Dimensions of brand equity: An investigation on higher education institutions. Asian Journal of Research in Social Sciences and Humanities, $6(5), 353-359$.

Miller, G. R., \& Nicholson, H. E. (1976). Communication inquiry: A perspective on a process. Reading: Addison-Wesley.

Morgan, R. M. (2000). Relationship marketing and marketing strategy: The evolution of relationship marketing strategy within the organization. Thousand Oaks, CA: Sage.

Moussa, A., \& de Barnier, V. (2017). The effect of brand heritage on brand trust, brand equity, and brand perceived innovativeness: An exploratory research (An Abstract). Springer, Cham.

Mulhern, F. J., \& Padgett, D. T. (1995). The relationship between retail price promotions and regular price purchases. The Journal of Marketing, 59(4), 83-90.

Niazi, M. A., Ghani, U., \& Aziz, S. (2012). The emotionally charged advertisement and their influence on consumers'attitudes. International Journal of Business and Social Science, 3(1), 307-320.

Nigam, A., \& Kaushik, R. (2011). Impact of brand equity on customer purchase decisions: an empirical investigation with special reference to hatchback car owners in central Haryana. International Journal of Computational Engineering $\&$ Management, 12, 121-128.

Nunnally, J. C. (1967). Psychology theory. New York: McGraw Hill.

Rafique, M. (2012). Impact of celebrity advertisement on customers' brand perception and 
purchase intention. Asian Journal of Business and Management Sciences, 1(11), $53-67$.

Rajendran, K. N., \& Tellis, G. J. (1994). Contextual and temporal components of reference price. The Journal of Marketing, 58(1), 22-34.

Rangaswamy, A., Burke, R. R., \& Oliva, T. A. (1993). Brand equity and the extendibility of brand names. International Journal of Research in marketing, 10(1), 61-75.

Reijonen, H., Hirvonen, S., Nagy, G., Laukkanen, T., \& Gabrielsson, M. (2015). The impact of entrepreneurial orientation on b2b branding and business growth in emerging markets. Industrial Marketing Management, 51, 35-46.

Ronstadt, R. (1990). The educated entrepreneurs: A new era of entrepreneurial education is beginning. Entrepreneurship education: Current developments, future directions, 69-88.

Sari, D., \& Kusuma, B. (2014). Does luxury brand perception matter in purchase intention? A comparison between a Japanese brand and a German brand. ASEAN Marketing Journal, 4(1), 50-63.

Shah, S. S. H., Aziz, J., Jaffari, A. R., Waris, S., Ejaz, W., Fatima, M., \& Sherazi, S. K. (2012). The impact of brands on consumer purchase intentions. Asian Journal of Business Management, 4(2), 105-110.

Shim, S., \& Gehrt, K. C. (1996). Hispanic and native American adolescents: An exploratory study of their approach to shopping. Journal of Retailing, 72(3), 307-324.

Sikri, S., \& Ramaswami, S. (1992). Brand equity effects on consumers' responses to prices in retail (Tech. Rep.). Iwoa Univesrsity, working paper, 92-02.

Soenyoto, F. (2015). The impact of brand equity on brand preference and purchase intention in Indonesia's Bicycle Industry: A case study of polygon. iBuss Management, 3(2), 99-108.

Stayman, D. M., \& Aaker, D. A. (1988). Are all the effects of ad-induced feelings mediated by a ad? Journal of Consumer Research, 15(3), 368-373.

Thoumrungroje, A., \& Racela, O. (2013). The contingent role of customer orientation and entrepreneurial orientation on product innovation and performance. Journal of Strategic Marketing, 21(2), 140-159.

Varian, H. R. (1980). A model of sales. The American Economic Review, 70(4), 651-659.

Vigneron, F., \& Johnson, L. W. (2004). Measuring perception of brand luxury. Journal of Brand Management, 11(6), 484-506.

Walas, B., \& Celuch, K. (2014). Certification in tourism as an element of quality management-theoretical aspects and entrepreneurs' attitudes. International Journal of Business Quantitative Economics and Applied Management Research, 1(2), $62-71$.

Winters, L. C. (1991). Brand equity measures: some recent advances. Marketing Research, $3(4), 70$.

Wu, P. C., Yeh, G. Y. Y., \& Hsiao, C. R. (2011). The effect of store image and service quality on brand image and purchase intention for private label brands. Australasian Marketing Journal (AMJ), 19(1), 30-39.

Yang, M., \& Gabrielsson, P. (2017). Entrepreneurial marketing of international high-tech business-to-business new ventures: A decision-making process perspective. Industrial 
Marketing Management, 64, 147-160. doi: http://dx.doi.org/10.1016/j.indmarman .2017.01.007

Zeithaml, V. A. (1988). Consumer perceptions of price, quality, and value: A means-end model and synthesis of evidence. The Journal of Marketing, 52(3), 2-22. 